\title{
The Spatial and Temporal Variations of Ichythyofauna and Water Quality in the Crocodile River (East), Mpumalanga, South Africa
}

\author{
M. I. Soko ${ }^{*}$, T. Gyedu-Ababio ${ }^{2}$ \\ ${ }^{1}$ Department of Water and Sanitation, Nelspruit, South Africa \\ ${ }^{2}$ Inkomati-Usuthu Catchment Management Agency, Nelspruit, South Africa \\ Email: Sokom@dwa.gov.za, thomasga@iucma.co.za
}

Received 24 January 2015; accepted 9 February 2015; published 12 February 2015

Copyright (C) 2015 by authors and Scientific Research Publishing Inc.

This work is licensed under the Creative Commons Attribution International License (CC BY). http://creativecommons.org/licenses/by/4.0/

(c) (i) Open Access

\begin{abstract}
The Crocodile River is situated in the north east of the Republic of South Africa. It is a large river basin with a total length of $320 \mathrm{~km}$ and draining a catchment of $10,450 \mathrm{~km}^{2}$. The water quality of this river is of high importance in sustaining the people and businesses relying on the sustainability of the river. The aim of the study was to use fish and water quality data to determine the present ecological state of the river and identifying the possible sources of pollution in the river. Multivariate statistical analysis was used to identify the main contaminants in the river at the various sections of the river. The results obtained indicated that species richness and diversity are high during low flow condition and the lower reaches had high species richness and diversity compared to the middle and upper reaches. The Fish Response Assessment Index indicated that the Ecological Class for the Crocodile River is mostly at C class beginning from the Kwena Dam downstream. Water quality constituents such as total dissolved solids and electrical conductivity increase with the increase in river distance in the downstream reaches. It was evident from this study that anthropogenic activities along the Crocodile River play a role in water quality deterioration and the subsequent distribution of fish during high and low flow conditions. The main sources of the pollution are believed to be agricultural activities in the upper reaches and a combination of industrial, domestic and agricultural activities in the middle and lower reaches of the Crocodile River.
\end{abstract}

\section{Keywords}

Fish, Water Quality, Nutrients, Anthropogenic Activities, Pollution

\footnotetext{
${ }^{*}$ Corresponding author.
}

How to cite this paper: Soko, M.I. and Gyedu-Ababio, T. (2015) The Spatial and Temporal Variations of Ichythyofauna and Water Quality in the Crocodile River (East), Mpumalanga, South Africa. Journal of Water Resource and Protection, 7, 152170. http://dx.doi.org/10.4236/jwarp.2015.73013 


\section{Introduction}

Anthropogenic activities result in a significant decrease in surface water quality of aquatic ecosystems in catchments [1]. The deterioration of the water resource is due to increased pollution caused by anthropogenic activities such as industry, urbanization, afforestation, mining, agriculture, power generation and accidental water pollution [2]. River inflows also contribute to main pollutants to the water resource in a catchment, thereby tending to induce serious ecological and sanitary problems [3] [4].

The production of unwanted by-product or waste of all man's activities is a characteristic of mankind, and inevitable in modern society. Thus, river ecosystems will continue to deteriorate unless they are managed in a sustainable way [5]. The pollution of rivers by human induced activity is now becoming a threat to water resource and its biodiversity. In South Africa environmental pollution problems started during the first half of the 19th century, with the development of towns and industries and associated accumulation of wastes in built-up areas. The Crocodile River catchment is recognized as one of the most water-stressed catchments in South Africa, a major concern considering the increased number of people who depend on it for their livelihood, including a large demand for water by emerging farmers [6].

Protecting the needs of the environment requires tools that can be used to monitor environmental conditions as well as for setting ecological objectives to ensure the proper and sustainable management of the resource [7]. The River Health Program (RHP) was developed to serve as a source of information regarding the overall ecological status of river ecosystems in South Africa. The RHP primarily makes use of in-stream and riparian biological communities to characterize the response of the aquatic environment to multiple disturbances. The rationale is that the integrity or health of the biota inhabiting the river ecosystems provides a direct and integrated measure of the health of the river as a whole [8]. The main aim of the study was to use biological indicators such as fish to identify the possible sources of pollution and determine the present ecological state of the river using multivariate statistical analysis and the Instream Response models.

\section{Materials and Methods}

\subsection{Study Area}

The Crocodile River (east) is in Mpumalanga Province in the north east of the Republic of South Africa. It is a relatively large river basin with a total length of approximately $320 \mathrm{~km}$ and draining a catchment area of about $10,450 \mathrm{~km}^{2}$ (Figure 1).

The various activities in the catchment include Forestry, Dry land agriculture, Irrigated agriculture, Nature conservation, Mining and quarrying, Domestic and Industrial.

\subsection{Ichythyofauna}

Fish surveys were conducted at the sites indicated on the map in Figure 1 during high and low flow conditions in the year 2013. During the survey an electric shocker (SAMUS-725MP) was used to immobilise the fish. The fish were collected in different velocity depth classes and for each flow depth class. The presence of features that provide cover for fish was taken into consideration. Information on the general habitat and cover preferences of fish species was obtained from the available literature and personal experience. Fish data collected in different velocity depth was kept separate for analysis and the results were recorded as a number of fish caught per time unit [9].

\subsection{Water Quality}

Thirty six water quality samples were collected from twelve sites of the study area during low flow period (June-August 2012) and high flow (December 2012-March 2013). Each site was visited three times during the survey and a polyethylene bottle was used to collect the water quality samples and in situ measurements of $\mathrm{pH}$, TDS, Salinity, Temperature, and Conductivity were taken using an YSI Multi meter (HQ40d). Certain water quality variables such as Ammonium, Chlorine, Nitrate, Sulphates, Phosphate, Manganese and Sodium were analyzed by Mpumamanzi Laboratory in Nelspruit and Waterlab in Pretoria. Historical water quality data was obtained from the Department of Water Affairs. 


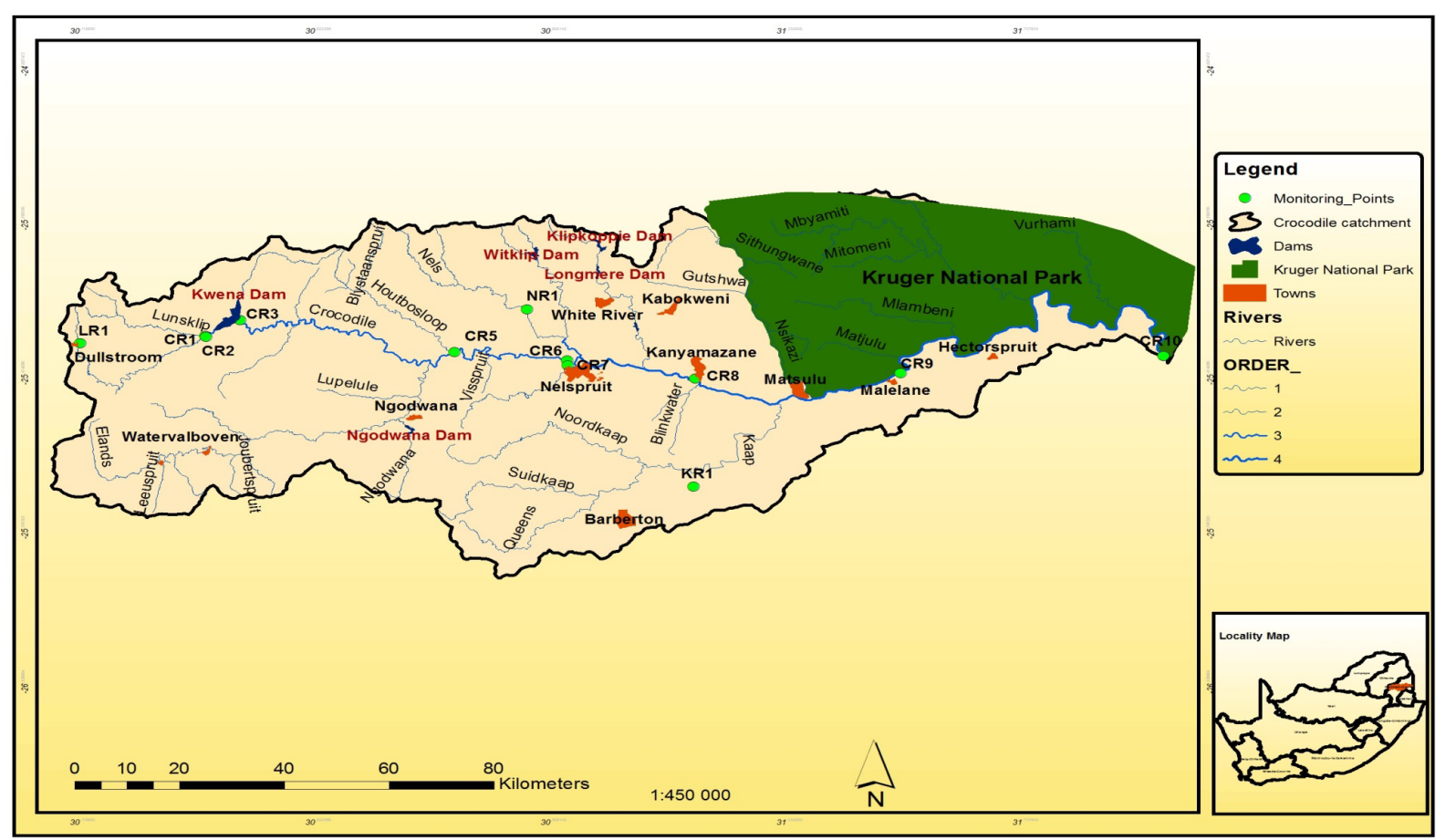

Figure 1. Map showing the monitoring sites in the Crocodile River Catchment.

\subsection{Data Analysis}

Analysis of data for fish focused on quantifying the spatial and temporal variation in species richness and abundance, and identification of environmental variables explaining variation across the study sites. The Statistical Product and Service Solutions (SPSS)was used to perform statistical analyses. A Detrended Correspondence Analysis (DCA) was performed to identify the strongest gradient of assemblage composition independent of the environmental variables and standard deviation redundancy analysis (RDA) was selected for the evaluation of the variability in the assemblage structure in relation to the measured environmental factors. The multivariate statistical analysis was performed using CANOCO version 4.5. The Fish Response Assessment Index (FRAI) was performed to determine the ecological condition of the river [10].

\section{Results}

\subsection{Ichythyofauna}

\subsubsection{Spatial and Temporal Trend Analysis}

A total of 1504 fish were caught in the Crocodile River and its tributaries during both high and low flow surveys, representing 30 species as indicated in Table 1 and Table 2 (Appendix). A highest number of species as indicated in Figure 2 were sampled during low flow at site CR9 and certain species such as Amphilius uranoscopus, Barbus unitaeniatus and Labeo cylindricus were sampled only during the low flow survey. Sites CR7, CR8 and CR10 followed a similar trend as site CR9 with high number of fish species sampled during the low flow. A polynomial trend line overlaid in Figure 2 indicated that the total number of fish species caught in the Crocodile River was higher in the middle (sites CR7 and CR8) and lower reaches (sites CR9 and CR10). The total number of species graph further indicated that during low flow conditions higher number of species occurs in the system compared with high flow conditions.

Sites CR1, CR2 and CR4 in the upper reaches of the Crocodile River had low diversity of species or only a small number of species were caught, especially at site CR1 where only one species (Barbus anoplus) occurs. The release of water from the Kwena Dam has resulted in natural changes at site CR4, immediately below the dam and this was observed by the limited diversity of species sampled at this site due to change in habitat as compared to other sites below the dam. 


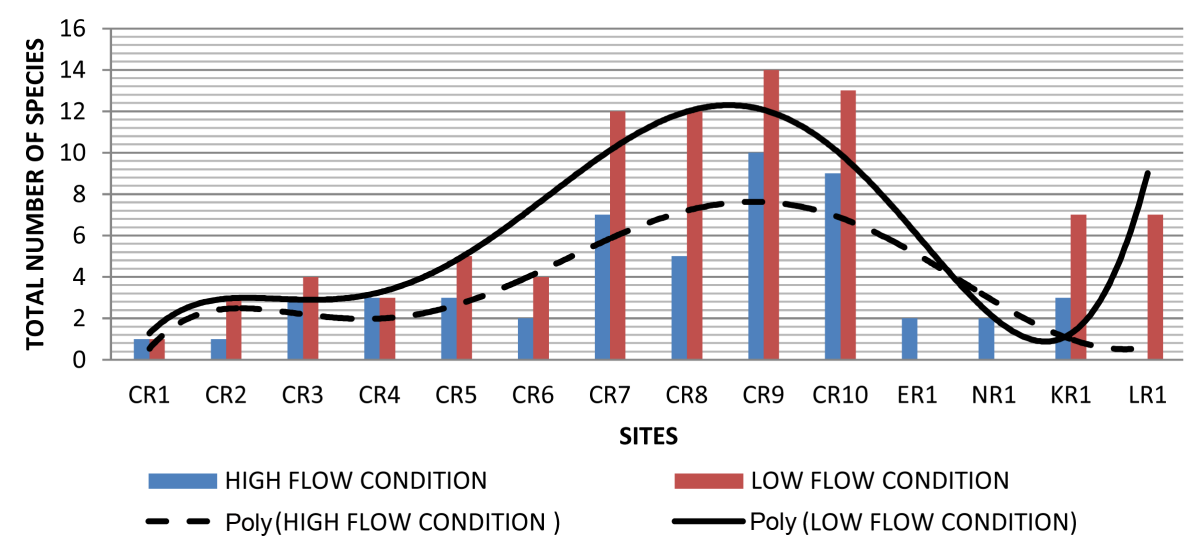

Figure 2. Total number of fish caught during the low flow and high flow surveys in the Crocodile River and its tributaries with a polynomial trendline.

\subsubsection{The Margalef's Species Richness for Ichythyofauna}

The polynomial trend line overlaid on the Margalef species richness graph (Figure 3), showed an increase in species richness and abundance at site CR9 during low flow condition. When comparing sites CR9 and CR10 during both flow conditions a deterioration of species richness and abundance was observed after the Malelane Town at site CR10. Site CR10 recorded species that prefer slow moving water like Tilapia rendalli, Labeocongoro [9], hence the lower reaches contain high species richness and abundance when compared to the middle and upper reaches of the river during both flow conditions.

The upper reaches sites CR1, CR2, CR3 which were above the Kwena Dam and CR4 which was immediately below the Kwena Dam had low species richness and abundance compared to the middle and lower reaches of the river during low flow condition. Site CR4 had high species richness when compared to other sites (CR5 and CR6) of the middle reaches during high flow condition. Although the sites upstream of the river had lower species richness site CR4 indicated relatively high species richness especially during high flow condition compared to the other upstream sites. After the confluence of the Elands River at site CR5 the fish species richness started to increase gradually passing through the Nelspruit Town (CR7) and Kanyamazane Town (CR8). A higher fish species richness and abundance was observed at site KR1 when compared with the other tributaries sampled during the survey.

\subsubsection{The Pielous Evenness Index for Ichythyofauna}

The polynomial trend line that has been overlaid on the Pielous evenness index indicated that sites CR1 and CR3 lack evenness during both flow conditions, which was an indication that these sites might be dominated by single species (Chiloglanis pretoriae) at site CR3 and Barbus anoplus at site CR1. At site LR1 fish species were also not evenly distributed during low condition (Figure 4).

\subsubsection{The Shannon Wiener Diversity Index for Ichythyofauna}

The Shannon Wiener diversity index also followed the same pattern as Pielous richness index. The polynomial trend line in Figure 5 indicated that diversity of fish species in the Crocodile River is high during low flow conditions. Site CR9 which was situated in the lower reaches of the Crocodile River was observed to have higher species diversity compared with all the sites monitored in the river during both flow conditions.

\subsubsection{Similarities}

A Bray-Curtis cluster analysis and NMDS ordination performed in order to obtain an indication of the temporal and spatial trends of fish communities in the Crocodile River (Figure 6(a)), indicated that there were seven distinctive groupings of sites formation in the river system. The formation of similarity grouping was observed at similarity value of $40 \%$ and $50 \%$ (Figure $6(\mathrm{~b})$ ). Site ER1 was the only tributary site that was grouped together with other sites in the Crocodile River during high flow.

Another group formation of sites CR3 and CR5 (during high flow condition) and CR4 (during both flow condition) was observed. The NMDS ordination (Figure 6(b)), for all the sites sampled in the Crocodile River and its tributaries also indicated the same grouping as the Bray-Curtis cluster analysis (Figure 6(a)). 


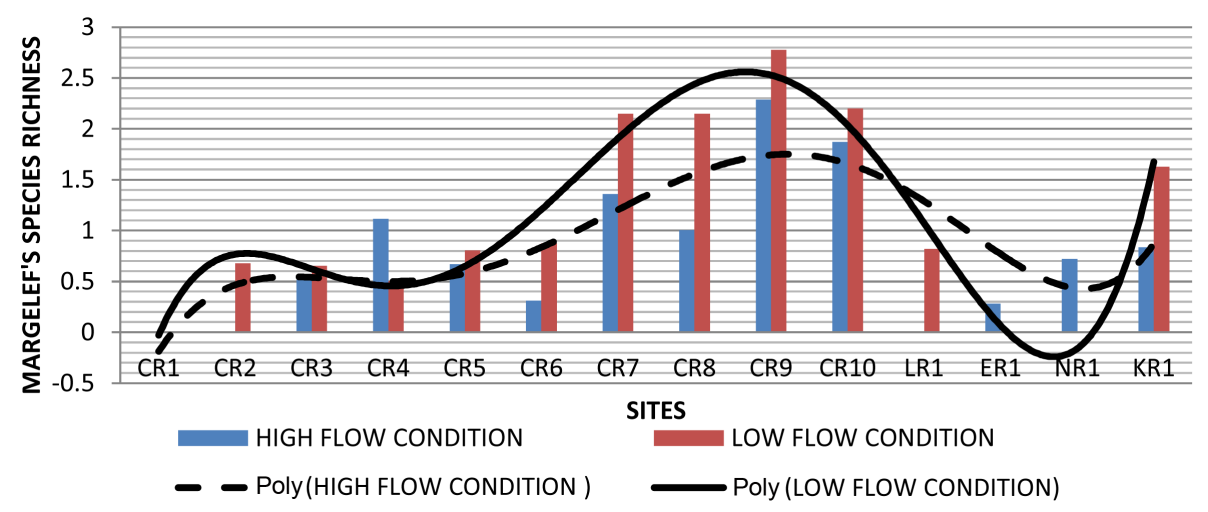

Figure 3. Margalef's species richness of the Crocodile River and some of its tributaries during low flow and high flow surveys.

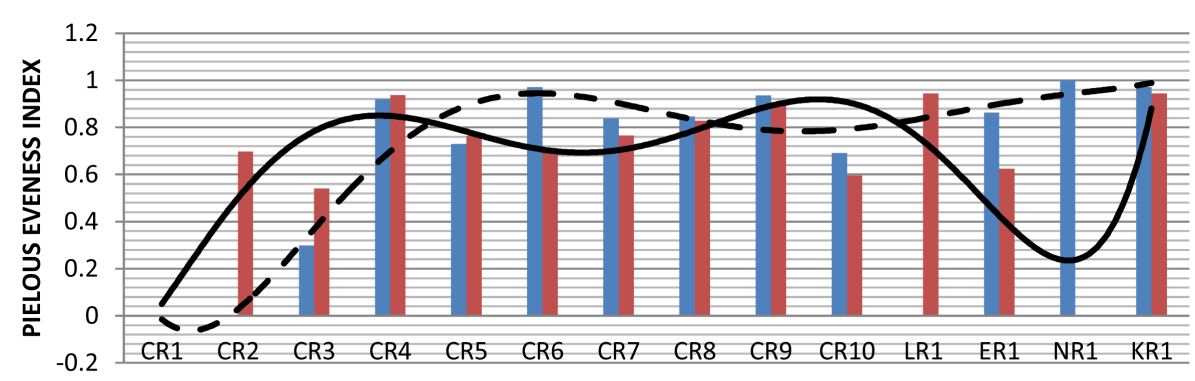

SITES
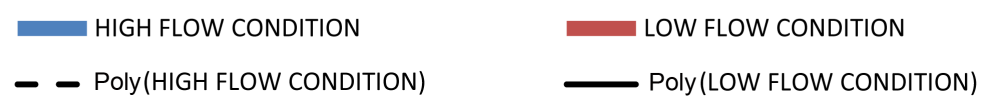

Figure 4. Pielous richness index of the Crocodile River and some of its tributaries during low flow and high flow surveys.

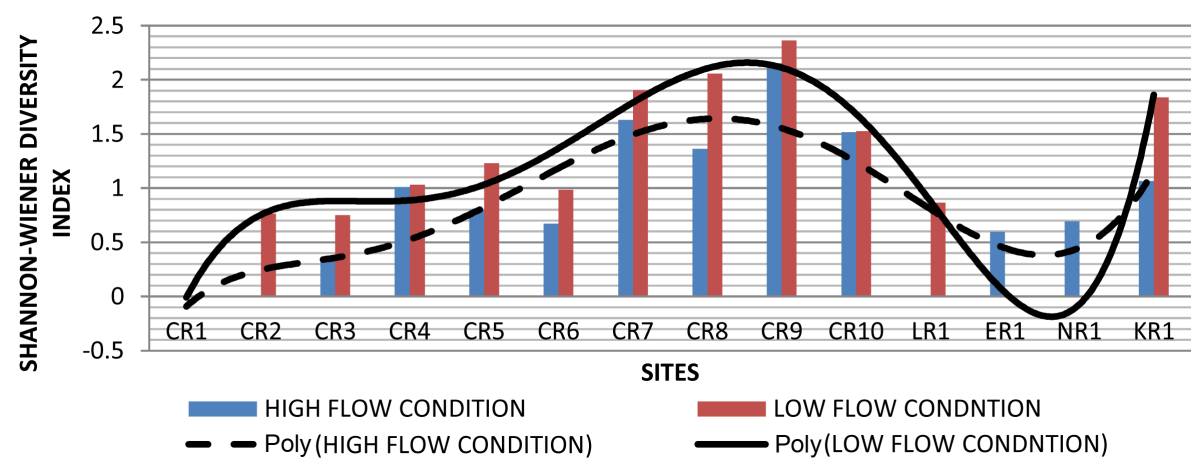

Figure 5. Shannon Wiener diversity index of the Crocodile River and some of its tributaries during low flow and high flow surveys.

\subsubsection{The K-Dominance for the Ichythyofauna}

The K-dominance curve (Figure 7), for the Ichythyofauna community indicated that during high flow condition $100 \%$ of single species dominated the fish communities at sites CR2 and CR1 and above 80\% at site CR3 (Figure 7). This species include Barbus anoplus (tolerant to pollution) at sites CR1 and CR2, while at site CR3 Chiloglanis pretoriae (species intolerant to pollution) dominated. The k-dominance curve further indicated that during high flow condition above $60 \%$ of single species dominated the fish communities at sites ER1 and CR6 while during low flow condition sites CR3, CR2, CR10 and CR4 were dominated by single species at the same percentage. 


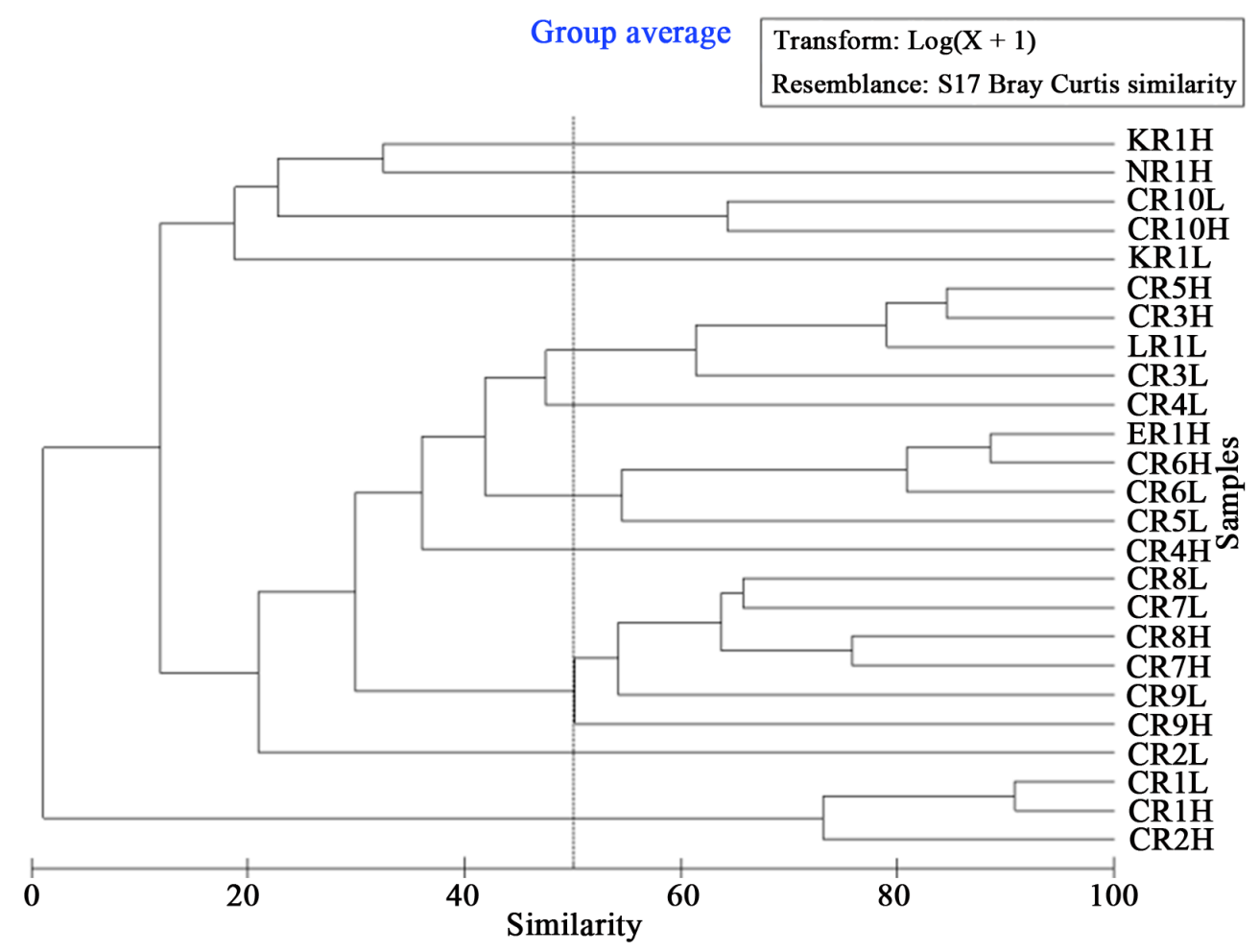

(a)

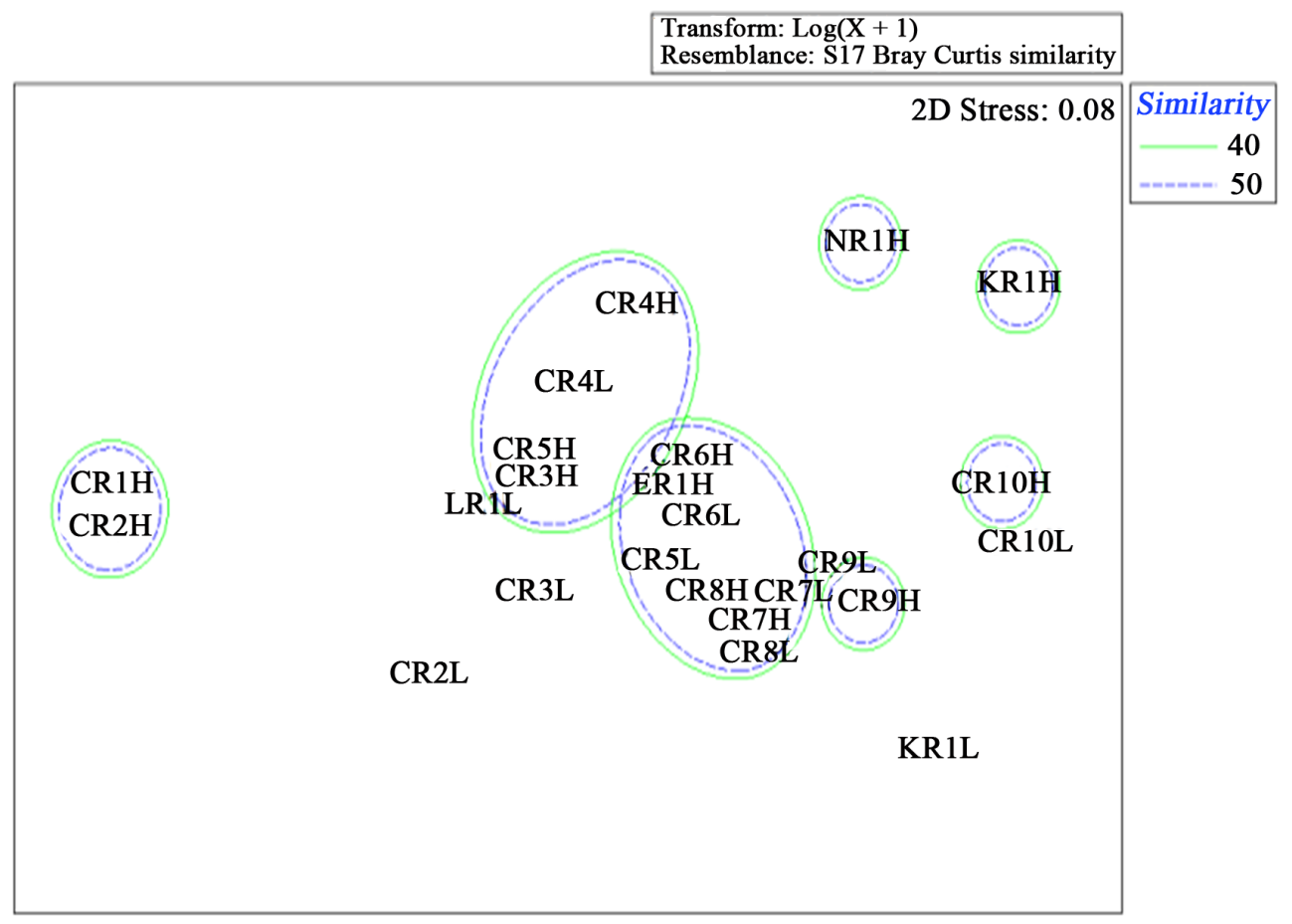

(b)

Figure 6. Bray-Curtis similarity matrix-based cluster analysis (a) and two dimensional representation of the NMDS ordination (b) of the Ichythyofauna collected in the Crocodile River and its tributaries during low flow and high flow conditions. The NMDS ordination was completed with 30 iterations and showed a stress of 0.08 . 


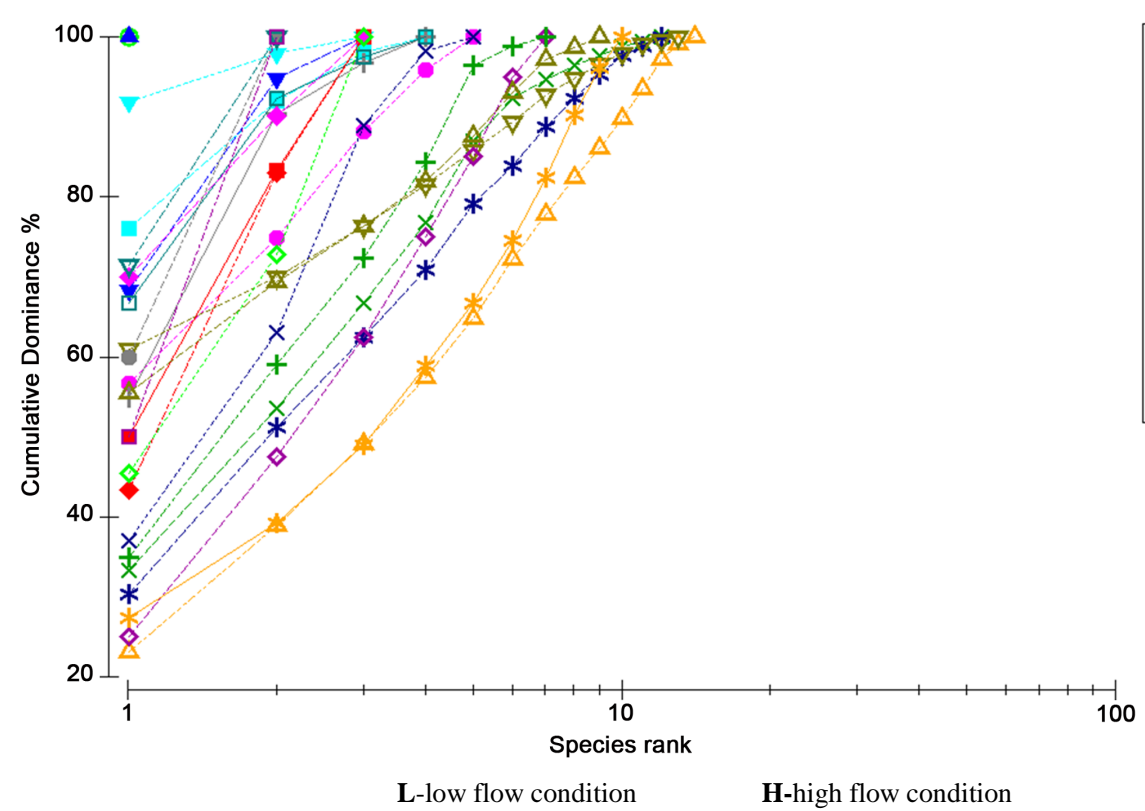

Figure 7. Ranked species K-dominance curves for the Ichythyofauna communities collected at the sites on the Elands and Crocodile Rivers during high and low flow conditions.

These sites were dominated by same species Chiloglanis pretoriae except site CR10 which was dominated by species such as Barbus viviparus (moderately tolerant) and site CR6 which was dominated by Labeobarbus marequensis.

\subsubsection{The RDA Triplot with Environmental Variables}

The RDA triplot for both flow regimes (Figure 8), showed a similar trend as with Bray-Curtis similarity matrices and NMDS plot (Figure 6), that there were similarities of sites in the Crocodile River and its tributaries. The distance between the sampling sites in the diagram indicated the similarity of their fish community as they were measured by their Euclidean distance.

The environmental variables super imposed (Figure 8), indicated that fish species such as Labeo cylindricus, Clarias gariepinus, Oreochromis mossambicus, Chiloglanis paratus, Micralestes acutidens, Labeo molybdinus, Chiloglanis swierstrai Van, Labeo congoro, Glossogobius callidus, Barbus viviparus, Hydrocynus vittatus, Barbus afrohamiltoni, Barbus radiatus and Barbus euteneus at sites CR7, CR9 and CR10L which was separated from sites CR7 and CR9 correlated positively with chloride, sulphate, total dissolved solids and magnesium in the river.

\subsubsection{Ecological Condition (Fish Response Assessment Index)}

The collected fish data for high and low flow conditions was further used to assess the Ecological Class of the river system using the Fish Response Assessment Index model (FRAI).The Fish Response Assessment Index Scores for site CR1 was $80.7 \%$ and $79 \%$ during low and high flow conditions respectively (Table 3). These scores were an indication that site CR1 Ecological Class was B/C (largely natural with few modifications) and class C (moderately modified). It was concluded that this site was in Ecological Class A which was an indication that the site was in a natural state or condition at that time [9].

At site CR2 which was a site upstream of the Kwena Dam the Ecological Class was lower compared with the upstream site CR1. The Fish Response Assessment Index score for site CR2 was rated 70.77\% and 70.3\% during high and low flow conditions and the ecological class was $C$ which was an indication that the site was moderately modified (Table 3). At site CR4 which was downstream of the Kwena dam the Ecological Class was lower than the sites upstream of the dam. The Ecological Class for site CR4 was C/D (57.9\%) and D (48\%) during low and high flow conditions respectively. At site CR5the Ecological Class C (moderately modified) (77.57\%) was higher compared with that at site CR4. The Elands River, site ER1 of the current study had an ecological class category C (69.5\%) moderately modified during high flow condition. This site has exotic 


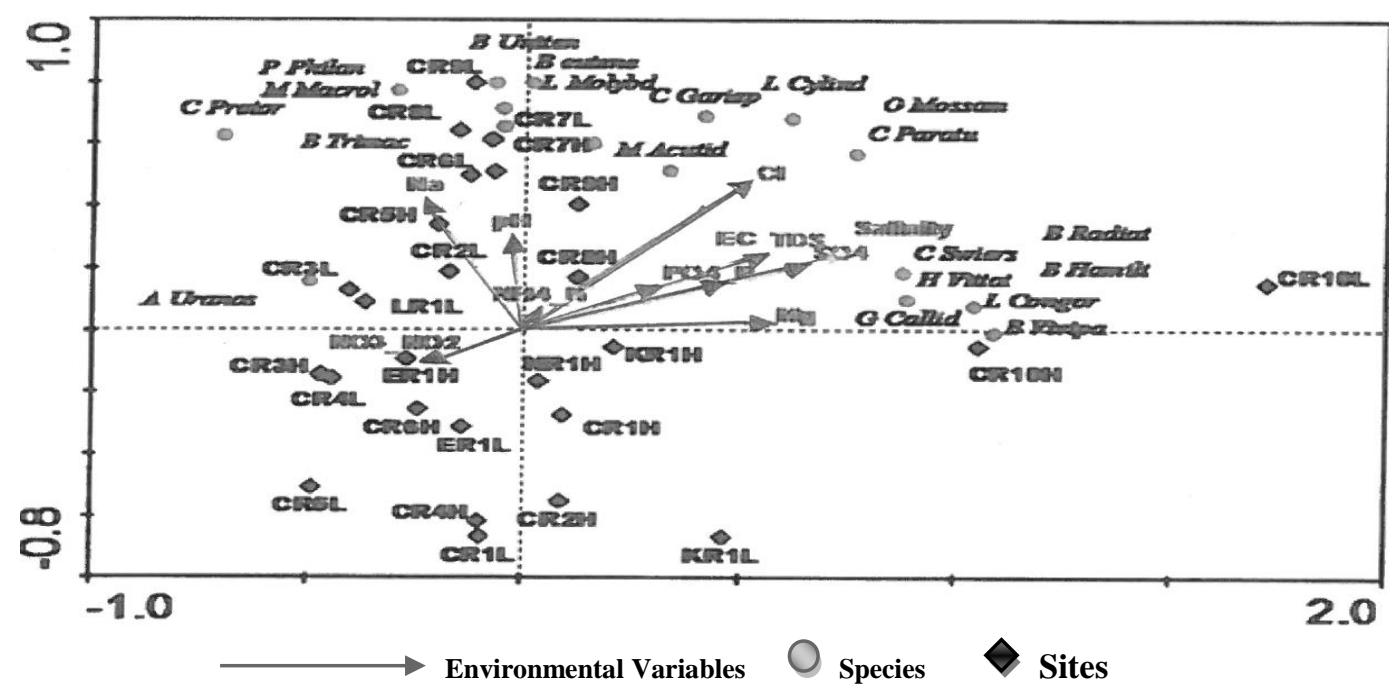

Figure 8. RDA tri-plot illustrating the similarities in the fish communities between the various sites and surveys with the physico-chemical variables superimposed. The tri-plot describes $61.8 \%$ of the variation with $34.5 \%$ being described on the first axis and $38.9 \%$ on the second axis. Only the species of with more than $20 \%$ is explained by the model is visualised.

Table 3. Fish response assessment index score percentage for the crocodile river and its tributaries.

\begin{tabular}{|c|c|c|c|c|}
\hline \multirow{2}{*}{ Sites Names } & \multicolumn{4}{|c|}{ Fish Response Assessment Index Score Percentage } \\
\hline & Low Flow (FRAI \%) & Ecological Class & High Flow (FRAI \%) & Ecological Class \\
\hline CR1 & 80.7 & $\mathrm{~B} / \mathrm{C}$ & 79 & $\mathrm{C}$ \\
\hline CR2 & 70.3 & $\mathrm{C}$ & 70.77 & $\mathrm{C}$ \\
\hline CR3 & 70 & $\mathrm{C}$ & 71.2 & $\mathrm{C}$ \\
\hline CR4 & 57.9 & $\mathrm{C} / \mathrm{D}$ & 48 & $\mathrm{D}$ \\
\hline CR5 & 77.57 & $\mathrm{C}$ & 64 & $\mathrm{C}$ \\
\hline CR6 & 78.7 & $\mathrm{C}$ & 71.5 & $\mathrm{C}$ \\
\hline CR7 & 79 & $\mathrm{C}$ & 72.2 & $\mathrm{C}$ \\
\hline CR8 & 79.2 & $\mathrm{C}$ & 78.3 & $\mathrm{C}$ \\
\hline CR9 & 77.7 & $\mathrm{C}$ & 77 & $\mathrm{C}$ \\
\hline CR10 & 72.7 & $\mathrm{C}$ & 71 & $\mathrm{C}$ \\
\hline LR1 & 69.2 & $\mathrm{C}$ & Not sampled & \\
\hline ER1 & 79.9 & B & 69.5 & $\mathrm{C}$ \\
\hline NR1 & 50 & $\mathrm{D}$ & Not sampled & \\
\hline KR1 & 68 & $\mathrm{C}$ & 65.2 & $\mathrm{C}$ \\
\hline
\end{tabular}

species such as Oncorhynchus mykiss (Rainbow trout) and Micropterus salmoides (Largemouth bass)which are known to have an impact (as predator) on the indigenous species. Downstream of the Nelspruit and Kanyamazane town, the river is mostly dominated by pools and limited riffles. During the current study these sites (CR7 and CR8) of the Crocodile River was in Ecological Class C (71.5\%) which was the same ecological class obtained by [9]. This stretch of the river has high diversity of fish and approximately eighteen species occur here but during 
the survey only thirteen of the expected species were sampled. Sites CR9and CR10 which forms part of the lower reach of the Crocodile River in the current study was found to be moderately modified with an Ecological Class C class. The sites recorded Ecological Class percentage of $77.7 \%$ and $72.7 \%$ respectively during the low flow conditions. Sites CR9 and CR10 were mostly dominated by species that prefer slow flowing water such as Tilapia sparmanii, Tilapia rendalli and Labeo congoro and only twenty fish species out of the thirty six species expected were caught in this reach. Sensitive species such as Amphilius uranoscopus, Chiloglanis pretoriae and Chiloglanis paratus were available in this segment although they were in low abundance as this segment was dominated by pools and rapids. This site was also known to contain species such as Hypophthalmichthys molitrix which is likely to compete for food and habitat with planktivorous fish and with post larvae and early juvenile state of most native fish species. The Kaap River which was site KR1 of the current study had an Ecological Class C (68.8\%) indicating that the river was moderately modified and species such as Chiloglanis swierstrai and Barbus brevipinnis were only sampled during low flow condition in low abundance. Site LR1 had an Ecological Class C (moderately modified) class with 69.2\% during low flow condition and it was sampled once during the survey. Site NR1 had an Ecological Class D (largely modified) with 50\% during low flow condition.

\subsection{Water Quality}

The physical and chemical variables analysed for water quality indicated that siteCR3 had a higher concentration of nitrate compared with all the sites sampled in winter with a mean value of $7.3 \mathrm{mg} / \mathrm{L}$ and a mean value 2.4 $\mathrm{mg} / \mathrm{L}$ in summer. A high concentration of phosphate at site CR7 with a mean value of $0.7 \mathrm{mg} / \mathrm{L}$ was recorded in winter. Ammonium recorded a mean value of $0.1 \mathrm{mg} / \mathrm{L}$ in winter at sites CR4, CR6, CR9 and CR10. Nitrate and phosphate had high concentrations at site CR10 in summer with mean values of $4.1 \mathrm{mg} / \mathrm{L}$ and $0.4 \mathrm{mg} / \mathrm{L}$ respectively. Water quality constituents such as total dissolved solids, electrical conductivity and salinity in the Crocodile River increased with the river flow distance downstream during summer months (Table 4 and Table 5 (Appendix)). At site ER1 a high concentration of TDS with a mean value of $528 \mathrm{mg} / \mathrm{L}$ and Salinity with a mean value of 0.358 (ppt) both in summer were also recorded (Table 4 (Appendix)). Chloride recorded a mean value of $47.3 \mathrm{mg} / \mathrm{L}$ in winter. The middle part of the Crocodile River system was characterized by the presence of solid waste and industrial effluent or run off, sewage discharge and domestic run off contributing to increase in nutrients as observed in this study. Salinity in the middle part of the Crocodile River was higher compared to the upper reaches and was associated with the various activities taking place in this area. At site KR1 high concentration of salinity with a mean value of 0.315 (ppt), TDS with a mean value of $460 \mathrm{mg} / \mathrm{L}$ was recorded during summer months (Table 4 (Appendix)). A high concentration of electrical conductivity with a mean value of $58.8 \mathrm{mS} / \mathrm{m}^{-1}$ was measured during winter month (Table 5 (Appendix)).

\section{Statistical Analysis}

The Bray-Curtis similarity for water quality for both high and low flow conditions (Figure 9(a)), indicated that although there were similarities within sites in the Crocodile River and its tributaries, disimilarities were also observed from the cluster analysis at different percentages.

The cluster analysis indicated similarity of sites within the Crocodile River and its tributaries at similarity value of $80 \%$ where a group formation of all the sites was observed. Another site grouping was observed at similarity of approximately 95\%.The NMDS ordination for all the sites sampled during both high and low flow conditions (Figure 9(b)) indicated the same group formation as the Bray-Curtis Cluster analysis and the generated stress for the NMDS was 0.04. The NMDS ordination further indicated that during high and low flow condition sites CR3 and CR4 formed group formation with less than one site per group which was an indication that they were separated from the rest of the sites.

The Principal Component Analysis Figure 10, indicated that sodium was by far the highest impact parameter in the bi-plot followed by ammonium and nitrate, while magnesium and phosphate variables had the lowest. A correlation between a group of sites and water quality constituents such as chlorine, TDS, electrical conductivity, sulphate and $\mathrm{pH}$ was observed.

Clustering of sites especially in the middle and lower reaches of the Crocodile River and its tributaries was observed. A separation of sites (indicating dissimilarity) especially between the upper reaches and some of the middle and lower reaches of the Crocodile River was also observed. A high Euclidean distance was observed between sites CR3 and CR10 (both flow conditions). 


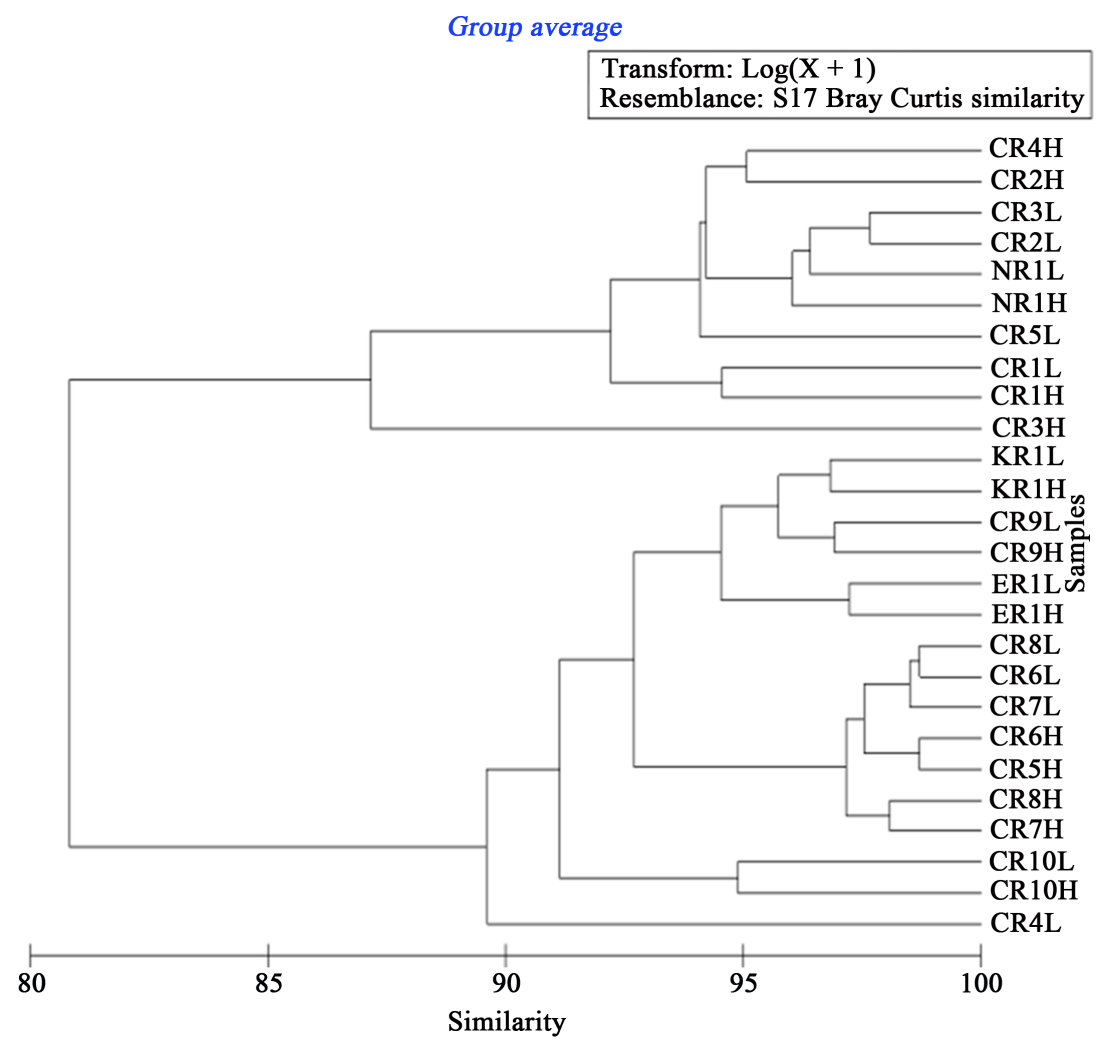

(a)

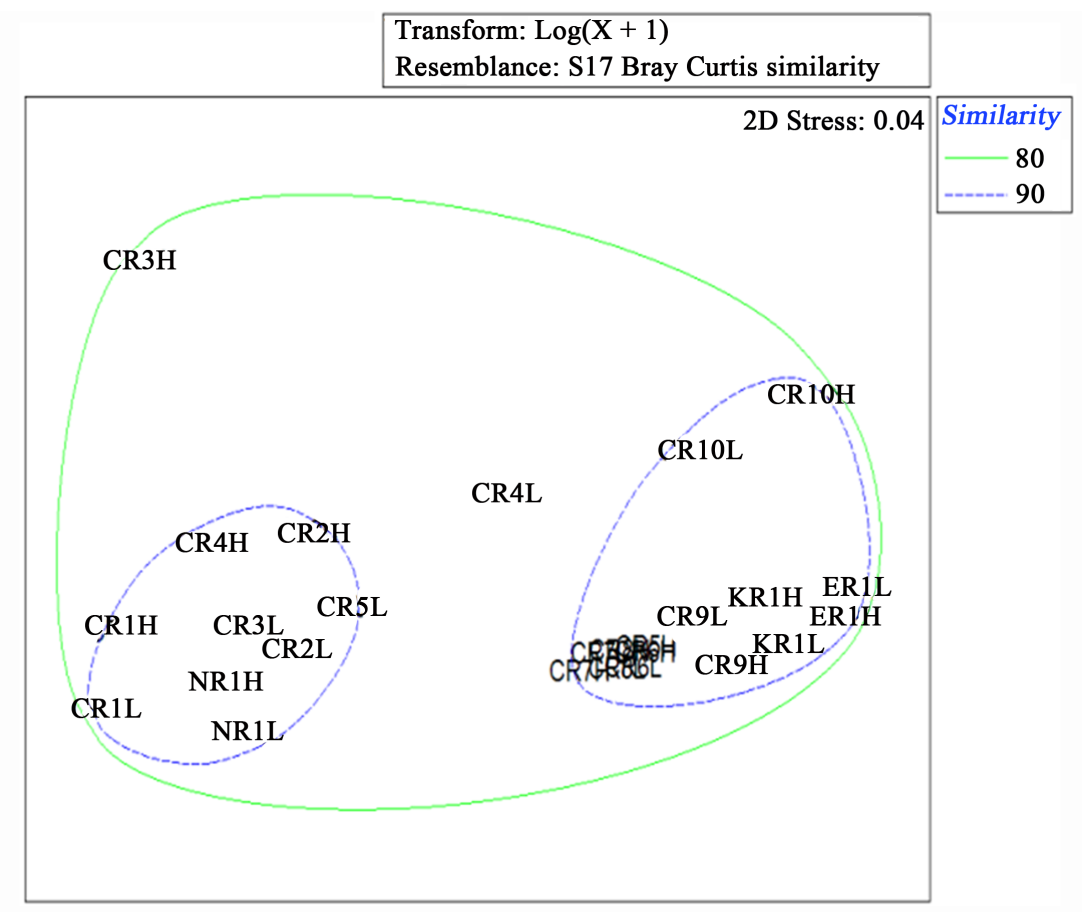

(b)

Figure 9. Bray-Curtis similarity matrix-based on cluster analysis (a) and a two dimensional representation of the NMDS ordination (b) of the physical and-chemical variables sampled at the sites Crocodile Rivers and tributaries during high and low flow conditions. The NMDS ordination was completed with 30 iterations and showed a stress of 0.04 . 

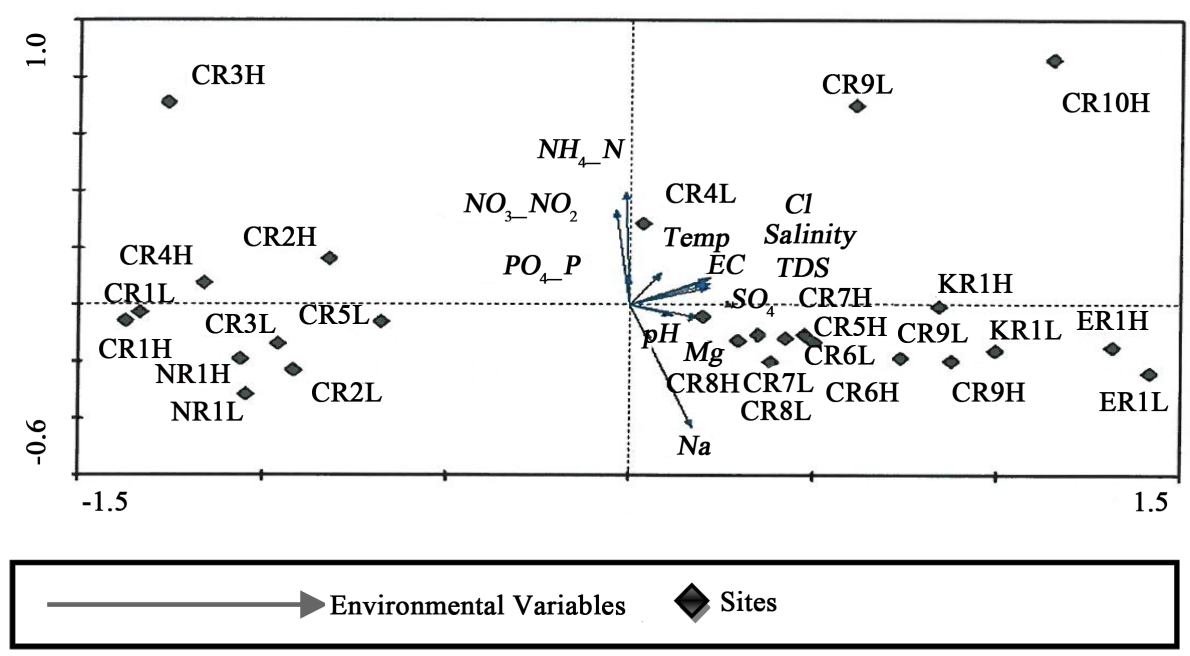

Figure 10. PCA bi-plot illustrating the similarities between the various sites during different seasons based on the physico-chemical characteristics of the water with the physico-chemical variables superimposed. The bi-plot describes $90.6 \%$ of the variation with $80.5 \%$ described on the first axis and $9.1 \%$ on the second axis.

\section{Discussion}

\subsection{Ichythyofauna}

Species richness, diversity and distribution increased longitudinally in the lower reaches of the Crocodile River. The variation of species richness, diversity and distribution during low and high flow condition was attributed to the changes in water quality, habitat and flow modification. The decrease in species richness in the upper reaches of the Crocodile River can also be attributed to the Kwena Dam which reduces fish richness and abundance upstream by limiting fish movement. This confirms an earlier study in the same river [9]. Other studies conducted in subtropical small stream of the Haungshan Mountain in China indicated that dam construction can reduce upstream fish richness by eliminating or reducing fish movement and it can also replace native warm water assemblages with non-native cold-water assemblages by decreasing downstream water temperature [11]-[15]. The high species richness at site CR4 during high flow condition was due to the presence of fish species which prefers certain substrate and food availability. The lack of species distribution in the River was associated with habitat diversity, water quality characteristics and the presence of predator species especially in the upper reaches at site CR1 which was dominated by one species (Barbus anoplus). The presence of this species at site CR1 indicated that the upper reaches of the Crocodile River was prone to change in water quality as this species tolerate poor water quality [9].

The formation of groupings within the sites was due to the fact that they had similarities in species occurrence within specific sites. The separation of sites CR2, KR1 and CR3 during low flow condition from the rest of the grouping was linked to change in water quality as many agricultural activities occur at these sites. A group formation of sites CR1 and CR2 was observed during high flow condition and this was due to species composition within the sites. The dominance of species such as Chiloglanis pretoriae, Barbus anoplus and Barbus viviparus in the river (Figure 6) was also attributed to the change in habitat preference for other species occurring at the sites as fish communities in a river are structured typically by substrate complexity, stream flow and water quality [16]. The presence of the Chiloglanis pretoriae in the upper reaches of the Crocodile River during low flow condition indicated that the river has good water quality while the presence of Barbus viviparus in the downstream reaches indicated that the lower reaches might be polluted from industrial and agricultural activities along the river.

It was clear that the ecological class for the Crocodile River system was low during high flow condition as compared to the low flow condition (Table 3), and this was due to the fact that during high flow condition, it was not possible to sample all the fish habitats in some segments of the river. Thus, fish species such as Labeo polylepis, Tilapia sparmanii, Oreochromis mossambicus, Micralestes acutidens and Chetia brevis Jubb, 1968 were present in low abundance during the survey. The deterioration of the ecological class of the upper reaches 
was attributed to the presence of predator species such as Oncorhychus mykiss and water quality changes that affected the presence of the species such as Amphilius uranoscopus. Species such as Chiloglanis bifurcus was not sampled during the current survey and the 1996 survey in this segment but it was sampled in 1978. However, a single specimen was again caught in 1998 [9]. The presence of the Kwena Dam also has an impact on the migratory species that are within the segment as it inhibits their movement. A study conducted in the Crocodile River concluded that site CR2 had an Ecological Class C (79.9\%), which was close to a B class [17]. This was an indication that the site was slightly deteriorating in species availability. Downstream of the Kwena dam the Ecological Class was low compared to site CR4. The Ecological Class for site CR4was C/D (57.9\%) and D (48\%) during low and high flow condition respectively. A study conducted by [18], concluded that site CR4 was in Ecological Class C (moderately modified) while other studies concluded that the site was in Ecological Class B (largely natural with few modification) [9]. This is an indication that the ecological class status of site CR4 has deteriorated. The deterioration of the ecological status is due to the change of habitat and flow modification as a result of the release of water from the Kwena dam. At site CR5the Ecological Class improved from class C/D to an Ecological Class C (77.57\%) which indicated that the segment was moderately modified and this can be due to change in flow condition also caused by the Kwena Dam, weirs and influx of water coming from the Elands River. Exotic fish species such as Xiphophorus helleri Heckel, 1848 which has a small impact (such as feeding habit due to its high number) on the indigenous species also occurs in this segment. The Elands River, site ER1 of the current study had an ecological class category C (69.5\%) moderately modified. This site has exotic species such as Oncorhychus mykiss (rainbow trout) and Micropterus salmoides (largemouth bass) which are known to predate on the indigenous species. A study conducted by [18], indicated that site ER1 has Ecological Class B during low flow condition which indicated that the site was largely natural with few modifications. The low Ecological Class of this site for the current study was due to the fact that the species was responding to a change in water quality and other factors such as the influx of effluent coming from the processing of paper mill which caused an increase in water volume downstream of the mill.

The change in water quality and the over abstraction of water which result in change in flow pattern of the river might be the causes for the absence of other species such as Opsaridium peringueyi which is a species that prefer good water quality. Its absence also indicated that the sites might have deteriorated slightly in water quality. The absence of other species such as Macasenius macrolepidotus at sites CR7 and CR8 was due to lack of habitat preference as indicated above and poor water quality caused by agricultural activities and industries. Agricultural, mining and industrial activities in this vicinity were believed to have an influence on the water quality on the sites.

\subsection{Water Quality}

The high concentration of nitrates in winter at site CR3 (Table 5) which is situated in the upper reaches of the Crocodile River was associated with fertilizer application for agricultural purposes and cattle feeds. The upper reaches of the Crocodile River had good water quality, but susceptible to eutrophication due to trout farming in the area [9]. The increase in concentration of water quality constituents such as salinity, total dissolved solid and electrical conductivity longitudinally in the lower reaches was attributed to the presence of agricultural, urban run-off and industrial effluents coming from the Nelspruit Town. Industrial effluent from a paper mill and sewage effluent were also associated with the high concentration of chloride in the river. Studies concluded that the middle section of the Crocodile River had high nutrient concentration [9]. The high salinity and electrical conductivity measured at site KR1 was associated with abandoned mine which results in underground seepage and agricultural activities. This finding is similar to the findings of [19]. Agricultural, urban and rural run-offs, industrial effluent from Malelane Town played a huge role in the increase in concentration of water quality constituents such as chloride, magnesium, electrical conductivity and total dissolved solid during summer months as higher sediment loads were deposited in the river as depicted by sites CR9 and CR10. A high concentration of nitrates and phosphate was also recorded at site CR10 which was attributed to the above mentioned activities.

The dissimilarities within sites in the Crocodile River were associated with the presence of different water qualityconstituents and different water use activities alongthe the river which contribute different discharge types. The NMDS ordination further indicated that during high and low flow conditions, sites CR3 and CR4 formed groupings of one site in a group which was an indication that they were separated from the rest of the sites due to the concentration of different water quality constituents which was linked to the utilization of fertilizer in the upper reaches of the Crocodile River. 


\section{Conclusions and Recommendations}

The multivariate statistical methods used indicated that richness of fish species in the Crocodile River and its tributaries increase longitudinally downstream with the increase in river flow distance. This is due to the presence of habitat complexity in the middle and lower reaches of the river. The Ecological Class using Fish Response Assessment Index showed that during low flow condition the Crocodile River is mostly at Ecological Class B (largely natural with few modification) above the Kwena Dam, but from downstream of the dam the Ecological Class was C (moderately modified), while its tributaries were in Ecological Class B (largely natural with few modifications). The deterioration of the Ecological Class of the Crocodile River when compared with other studies was mostly associated with change of water quality resulting from agricultural run-offs, industrial and sewage effluent in the main stem and mining seepage especially in the Kaap River tributary. Habitat modification due to flow regulation also contributed to the modification of the fauna. The concentration of TDS, electrical conductivity and salinity were found to increase with the increase in river flow distance downstream during both seasons. The high concentration of these water quality constituents indicated that the Crocodile River becomes more vulnerable to pollutants in the downstream reaches. The upper reaches of the Crocodile River was exposed to high level of nitrate during winter seasons. The high level of these water quality constituents was associated with agricultural return flow in the upper reaches. In the middle reaches of the Crocodile River, chloride and phosphate were found to be high in winter and magnesium was found to be high in summer. The high level of chloride and phosphate was associated with sewage effluent and agricultural return flows or run-offs from the Mbombela, Matsulu and Kanyamazane Towns.

The lower reaches of the Crocodile River was found to have poor water quality compared to the upper and the middle reaches. This was also confirmed by the k-dominance curve which indicated that during low flow condition fish communities at sites CR3 and CR4 were dominated by a single species namely Chiloglanis pretoriae while site CR10 was dominated by Barbus viviparus. The presence of Barbus viviparus species at site CR10 indicated that the site was poor in water quality as this species is tolerant to such condition. The change in water quality in the lower reaches was associated with agricultural, industrial, mining and sewage treatment effluent in the lower reaches of the river. These activities were also believed to be the source of pollution in the Crocodile River and its tributaries. The use of both biological indicators and water quality in assessing the health of the Crocodile River proved to be valuable. It is suggested that an eco-status approach should be followed when assessing the impact of the anthropogenic activities in the rivers as it gives an overview of what is happening in the catchment. The results obtained from this study give an indication of the ecological and water quality status of the Crocodile River and its tributaries. It also contributes to the understanding of the impact of anthropogenic activities such as agricultural, industrial and mining on a river system.

\section{References}

[1] May, A.M., Mutasem, E., Mark, D.S. and John, L.N. (2006) Factors Influencing Development of Management Strategies for the Abou Ali River in Lebanon I. Spatial Variation and Land Use. Journal of the Science of Total Environment, 362, 15-30. http://dx.doi.org/10.1016/j.scitotenv.2005.09.079

[2] Ashton, P.J., Hardwick, D. and Breen, C.M. (2008) Changes in Water Availability and Demand within South Africa's Shared River Basins as Determinants of Regional Social-Ecological Resilience. In: Burns, M.J. and Weaver, A., Eds., Exploring Sustainability Science: A Southern African Perspective, Stellenbosch University Press, Stellenbosch, 279310.

[3] Gibert, C.S. and Wendy, A.T. (2003) Watershed Scale Assessment of Nitrogen and Phosphorus Loadings in the Indian River Lagoon Basin. Environmental Management, 67, 363-372. http://dx.doi.org/10.1016/S0301-4797(02)00220-7

[4] Kunwar, P.S., Anirita, M. and Sarita, S. (2005) Water Quality Assessment and Apportionment of Pollution Sources of Gomti River (India) Using Multivariate Statistical Technique-A Case Study. Analytica Chimica Acta, 538, 355-374. http://dx.doi.org/10.1016/j.aca.2005.02.006

[5] Parsons, R. and Jolly, J. (1994) The Development of a Systematic Method for Evaluating Site Suitability for Waste Disposal based on Geohydrological Criteria. Report No. TT 67/94, Water Research Commission, Pretoria.

[6] DWAF (Department of Water Affairs And Forestry) (2004) Internal Strategic Perspectives, Inkomati Water Management Area. Report No. P WMA 05/000/00/0303. No.1, Department of Water Affairs and Forestry, Pretoria.

[7] Roux, J., Kempster, P.L., Kleynhans, C.J., Van Vliet, H.R. and Du Preez, H.H. (1999) Integrating Stressor and Response Monitoring into a Resource-Based Water-Quality Assessment Framework. Environmental Management, 23, 1530. http://dx.doi.org/10.1007/s002679900165 
[8] Karr, K.R. and Chu, E.W. (1997) Biological Monitoring and Assessment: Using Multimetric Indexes Effectively. EPA 235-R97-0001, University of Washington, Seattle.

[9] Kleynhans, C.J. (1999) The Development of a Fish Index to Assess the Biological Integrity of South African Rivers. Water SA, 25, 265-278.

[10] Kleynhans, C.J. (2008) River EcoClassification. Manual for EcoStatus Determination. Module D: Fish Response Assessment Index (FRAI). Report No TT332/08, No. 2, WRC, Pretoria.

[11] Holmquist, J.G., Schmidt-Gengenbach, J.M. and Yoshioka, B.B. (1998) High Dams and Marine-Freshwater Linkages: Effects on Native and Introduced Fauna in the Caribbean. Conservation Biology, 12, 621-630. http://dx.doi.org/10.1046/j.1523-1739.1998.96427.x

[12] March, J.G., Benstead, J.P., Pringle, C.M. and Scatena, F.N. (2003) Damming Tropical Island Streams: Problems, Solutions, and Alternatives. Bioscience, 53, 1069-1078. http://dx.doi.org/10.1641/0006-3568(2003)053[1069:DTISPS]2.0.CO;2

[13] Bonner, T.H. and Wilde, G.R. (2000) Changes in the Canadian River Fish Assemblage Associated with Reservoir Construction. Journal of Freshwater Ecology, 15, 189-198. http://dx.doi.org/10.1080/02705060.2000.9663736

[14] Minckley, W.L., Marsh, P.C., Deacon, J.E., Dowling, T.E. and Hendrick, P.W. (2003) A Conservation Plan for Native Fishes of the Lower Colorado River. Bioscience, 53, 219-234. http://dx.doi.org/10.1641/0006-3568(2003)053[0219:ACPFNF]2.0.CO;2

[15] Quinn, J.W. and Kwak, T.J. (2003) Fish Assemblage Changes in an Ozark River after Impoundment: A Long-Term Perspective. Transaction of the American Fisheries Society, 132, 110-119. http://dx.doi.org/10.1577/1548-8659(2003)132<0110:FACIAO >2.0.CO;2

[16] Gorman, O.T. and Karr, J.R. (1978) Habitat Structure and Stream Fish Communities. Ecology, 59, 507-515. http://dx.doi.org/10.2307/1936581

[17] Ferreira, M. (2005) A Study into the Anthropogenic Impacts Affecting the Elands River, Mpumalanga. MSc Thesis, University of Johannesburg, South Africa.

[18] Heath, R. and Claassen, M. (1999) The Use of Indigenous Fish Species for the Determination of Pesticide and Heavy Metal Loads. Report No 428/1/99, Water Research Commission, Pretoria.

[19] KNP (Kruger National Park) (2014) Information about the Crocodile River. http://www. winchestermarketing.com/ngwenya/index.php?pgid=3\&sid=2 


\title{
Appendix
}

Table 1. Expected fish species in the Crocodile River and its tributaries and the number of fish caught per site during high flow conditions (Kleynhans, 1999; KNP, 2014).

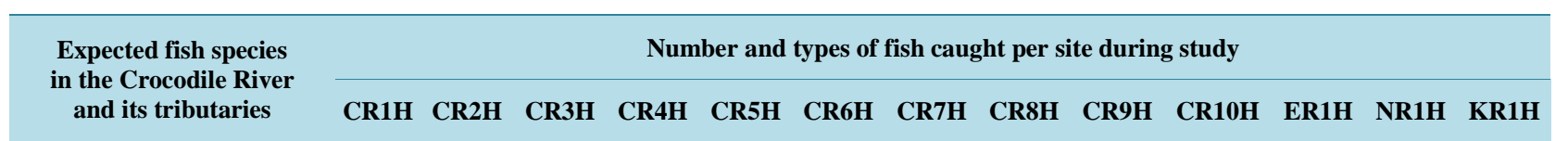

FAMILY: AMPHILIIDEA

Amphilius natalensis

(Boulenger, 1917)

Amphilius

uranoscopus (Pfeffer, 1889)

FAMILY: AMPHLLIDEA

Anguilla marmorata

(Quoy \& Gaimard 1824)

Anguilla mossambica
(Peters 1852)

\section{FAMILY: CYPRINIDAE}

\author{
Barbus anoplus \\ (Webber, 1897) \\ Barbusargenteus \\ (Günther, 1868) \\ Barbusbrevipinnis \\ (Jubb, 1966) \\ Barbuseutaenia \\ (Boulenger, 1904) \\ Barbusafrohamiltoni \\ (Crass, 1960) \\ Barbus neefi \\ (Greenwood, 1962) \\ Barbus paludinosus \\ (Smith, 1841) \\ Barbus radiatus \\ (Peters, 1853) \\ Barbus trimaculatus \\ (Peters, 1852) \\ Barbusunitaeniatus \\ (Günther, 1866) \\ Barbus viviparus \\ (Webber, 1897) \\ Barbus annectens
}

(Gilchrist \& Thompson, 1917)

Labeo congoro (Peters, 1852)

Labeo cylindricus (Peters, 1852)

\section{FAMILY: ANGUILLIDEA}

Labeo molybdinus (Du Plessis, 1963) 


\section{Continued}

Labeo rosae

(Teindachner, 1894)

Labeo ruddi

(Boulenger, 1907)

Labeobarbus marequensis (Smith, 1841)

Labeobarbus polylepis (Boulenger, 1907)

Opsaridium peringueyi (Gilchrist \& Thompson, 1913)

\section{FAMILY: MOCHOKIDEA}

Chiloglanis bifurcus (Jubb \& Le Roux, 1969)

\section{Chiloglanis paratus} (Crass, 1960)

Chiloglanis pretoriae (Van Der Horst, 1931)

Chiloglanis swierstrai (Van Der Horst, 1931)

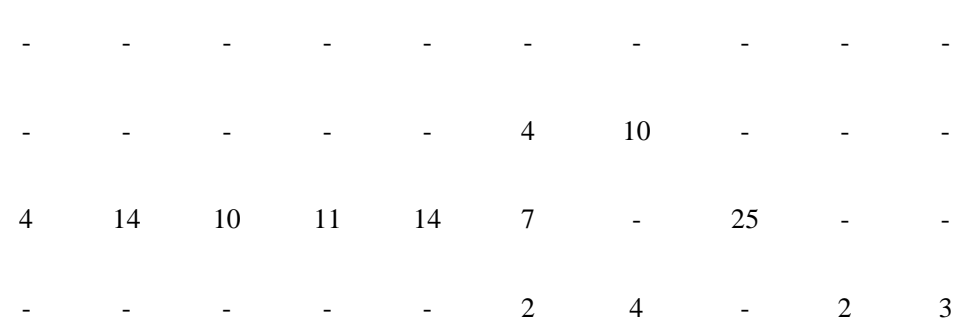

FAMILY: CLARIIDAE

Clarias gariepinus (Burchell, 1822)

\section{FAMILY: GOBIIDEA}

\section{Glossogobius callidus} (Smith, 1937)

Glossogobius guiris (Hamilton-Buchanan, 1822)

FAMILY: CHARACIDAE

\section{Hydrocynus vittatus} (Castelnau, 1861)

Micralestes acutidens (Peters, 1852)

\section{FAMILY: MORMYRIDAE}

Marcusenius macrolepidotus (Peters, 1852)

Petrocepheluswesselsi Kramer\& Van Der Bank, 2000

\section{FAMILY: CICHLIDAE}

Pseudocrenilabrus philander (Webber, 1897)

Tilapia rendalli (Boulenger, 1896)

Tilapia sparmanii (Smith, 1840) (Peter, 1852) 
Table 2. Expected fish species in the Crocodile River and its tributaries and the number of fish caught per site during low flow conditions (Kleynhans, 1999; KNP, 2014).

\begin{tabular}{|c|c|c|c|c|c|c|c|c|c|c|c|c|c|c|}
\hline \multirow{2}{*}{$\begin{array}{l}\text { Expected fish species } \\
\text { in the Crocodile River } \\
\text { and its tributaries }\end{array}$} & \multicolumn{14}{|c|}{ Number and types of fish caught per site during study } \\
\hline & CR1L & CR2L & CR3L & CR4L & CR5L & CR6L & CR7L & CR8L & CR9L & CR10L & LR1L & ER1L & NR1L & KR1L \\
\hline \multicolumn{15}{|c|}{ FAMILY: AMPHILIIDEA } \\
\hline $\begin{array}{l}\text { Amphilius natalensis } \\
\text { (Boulenger, 1917) }\end{array}$ & - & & 2 & - & - & - & - & - & - & - & - & - & - & - \\
\hline $\begin{array}{l}\text { Amphilius uranoscopus } \\
\text { (Pfeffer, 1889) }\end{array}$ & - & 1 & & 9 & 6 & & 1 & 2 & 4 & & 1 & - & - & - \\
\hline \multicolumn{15}{|c|}{ FAMILY: ANGUILLIDEA } \\
\hline $\begin{array}{c}\text { Anguilla marmorata } \\
\text { (Quoy \& Gaimard, 1824) }\end{array}$ & - & - & - & - & - & - & - & - & - & - & - & - & - & - \\
\hline $\begin{array}{l}\text { Anguilla mossambica } \\
\text { (Peters, 1852) }\end{array}$ & - & - & - & - & - & - & - & - & - & - & - & - & - & - \\
\hline \multicolumn{15}{|c|}{ FAMILY: CYPRINIDAE } \\
\hline $\begin{array}{l}\text { Barbus anoplus } \\
\text { (Webber, 1897) }\end{array}$ & 8 & - & - & - & - & - & - & - & - & - & 2 & - & - & \\
\hline $\begin{array}{l}\text { Barbus argenteus } \\
\text { (Günther, 1868) }\end{array}$ & - & - & - & 21 & - & - & - & - & - & - & - & - & - & \\
\hline $\begin{array}{l}\text { Barbus brevipinnis } \\
\quad \text { (Jubb, 1966) }\end{array}$ & - & - & - & - & - & - & - & - & - & - & - & - & - & 10 \\
\hline $\begin{array}{l}\text { Barbus eutaenia } \\
\text { (Boulenger, 1904) }\end{array}$ & - & - & - & - & - & - & 56 & 19 & 8 & - & - & - & - & 4 \\
\hline $\begin{array}{l}\text { Barbus afrohamiltoni } \\
\text { (Crass, 1960) }\end{array}$ & - & - & - & - & - & - & - & - & - & 8 & - & - & - & - \\
\hline $\begin{array}{c}\text { Barbus neefi } \\
\text { (Greenwood, 1962) }\end{array}$ & - & - & - & - & - & - & - & - & - & - & - & - & - & - \\
\hline $\begin{array}{l}\text { Barbus paludinosus } \\
\quad \text { (Smith, 1841) }\end{array}$ & - & - & - & - & - & - & - & - & - & - & - & - & - & - \\
\hline $\begin{array}{l}\text { Barbusradiatus } \\
\text { (Peters, 1853) }\end{array}$ & - & - & - & - & - & - & - & - & - & 3 & - & - & - & - \\
\hline $\begin{array}{l}\text { Barbus trimaculatus } \\
\quad \text { (Peters, 1852) }\end{array}$ & - & - & - & - & - & - & - & 8 & 11 & - & - & - & - & - \\
\hline $\begin{array}{l}\text { Barbus unitaeniatus } \\
\text { (Günther, 1866) }\end{array}$ & - & - & - & - & - & - & 17 & 5 & 2 & & - & - & - & - \\
\hline $\begin{array}{l}\text { Barbus viviparus } \\
\text { (Webber, 1897) }\end{array}$ & - & - & - & - & - & - & - & - & 1 & 142 & - & - & - & 5 \\
\hline $\begin{array}{l}\text { Barbus annectens } \\
\text { (Gilchrist \& Thompson, 1917) }\end{array}$ & - & - & - & - & - & - & - & - & - & - & - & - & - & - \\
\hline $\begin{array}{c}\text { Labeo congoro } \\
\text { (Peters, 1852) }\end{array}$ & - & - & - & - & - & - & - & - & - & 4 & - & - & - & - \\
\hline $\begin{array}{l}\text { Labeo cylindricus } \\
\text { (Peters, 1852) }\end{array}$ & - & - & - & - & - & - & 2 & 14 & 6 & 8 & - & - & - & - \\
\hline $\begin{array}{l}\text { Labeo molybdinus } \\
\text { ( Du Plessis, 1963) }\end{array}$ & - & - & - & - & - & - & - & 6 & 4 & - & - & - & - & - \\
\hline $\begin{array}{c}\text { Labeo rosae } \\
\text { (Steindachner, 1894) }\end{array}$ & - & - & - & - & - & - & - & - & - & - & - & - & - & 6 \\
\hline $\begin{array}{c}\text { Labeo ruddi } \\
\text { (Boulenger, 1907) }\end{array}$ & - & - & - & - & - & - & - & - & - & - & - & - & - & - \\
\hline
\end{tabular}




\section{Continued}

\begin{tabular}{|c|c|c|c|c|c|c|c|c|c|c|c|c|c|c|}
\hline $\begin{array}{l}\text { Cyprinus carpio } \\
\text { (Linnaeus, 1758) }\end{array}$ & - & - & - & - & - & - & - & - & - & - & - & - & - & - \\
\hline $\begin{array}{l}\text { Varicorhinusnel spruitensis } \\
\text { (Gilchrist \& Thompson, 1911) }\end{array}$ & - & - & - & - & - & - & - & - & - & - & - & - & - & - \\
\hline $\begin{array}{l}\text { Labeobarbus marequensis } \\
\text { (Smith, 1841) }\end{array}$ & - & - & - & - & 81 & 11 & 22 & 35 & 5 & 12 & - & - & - & 9 \\
\hline $\begin{array}{c}\text { Opsaridium peringueyi } \\
\text { (Gilchrist \& Thompson, 1913) }\end{array}$ & - & - & - & - & - & - & - & 14 & - & - & - & - & - & - \\
\hline $\begin{array}{l}\text { Labeobarbus polylepis } \\
\text { (Boulenger, 1907) }\end{array}$ & - & - & - & - & - & - & - & - & - & - & - & - & - & - \\
\hline & & & & FAI & LY: & $\mathrm{CHC}$ & KIDAI & & & & & & & \\
\hline $\begin{array}{l}\text { Chiloglanis bifurcus } \\
\text { (Jubb \& Le Roux, 1969) }\end{array}$ & - & - & - & - & 19 & - & - & - & - & - & - & - & - & - \\
\hline $\begin{array}{l}\text { Chiloglanisparatus } \\
\text { (Crass, 1960) }\end{array}$ & - & - & - & - & - & - & 9 & - & 9 & 15 & - & - & - & - \\
\hline $\begin{array}{l}\text { Chiloglanis pretoriae } \\
\text { (Van Der Horst, 1931) }\end{array}$ & - & 20 & 76 & 23 & 26 & 17 & 19 & 51 & 25 & - & 26 & - & - & - \\
\hline & & & & & IILY & LAR & DAE & & & & & & & \\
\hline $\begin{array}{l}\text { Clarias gariepinus } \\
\text { (Burchell, 1822) }\end{array}$ & - & - & - & - & - & 1 & 1 & & 4 & 1 & - & - & - & - \\
\hline & & & & & MILY & SOBI & DAE & & & & & & & \\
\hline $\begin{array}{l}\text { Glossogobius callidus } \\
\quad \text { (Smith, 1937) }\end{array}$ & - & - & - & - & - & - & - & - & - & 1 & - & - & - & - \\
\hline $\begin{array}{c}\text { Glossogobius guiris } \\
\text { (Hamilton-Buchanan, 1822) }\end{array}$ & - & - & - & - & - & - & - & - & - & - & - & - & - & - \\
\hline & & & & FA & LY: & IARA & IDAF & & & & & & & \\
\hline $\begin{array}{l}\text { Hydrocynus vittatus } \\
\text { (Castelnau, 1861) }\end{array}$ & - & - & - & - & - & - & - & - & - & 5 & - & - & - & - \\
\hline $\begin{array}{l}\text { Micralestes acutidens } \\
\quad \text { (Peters, 1852) }\end{array}$ & - & - & - & - & - & - & & & 17 & 3 & - & - & - & - \\
\hline & & & & FAI & LY: 1 & $\mathbf{R M}$ & RIDA & & & & & & & \\
\hline $\begin{array}{l}\text { Marcusenius macrolepidotus } \\
\text { (Peters, 1852) }\end{array}$ & - & - & - & - & - & - & 4 & 4 & - & - & - & - & - & - \\
\hline $\begin{array}{c}\text { Petrocephelus wesselsi } \\
\text { (Kramer\& Van Der Bank, 2000) }\end{array}$ & - & - & - & - & - & - & - & - & - & - & - & - & - & - \\
\hline FAMILY: CICHILIDAE & & & & & & & & & & & & & & \\
\hline $\begin{array}{l}\text { Oreochromis mossambicus } \\
\text { (Peter, 1852) }\end{array}$ & - & - & - & - & - & - & 3 & 2 & 8 & 21 & - & - & - & - \\
\hline $\begin{array}{c}\text { Pseudocrenilabrus } \\
\text { philander (Webber, 1897) }\end{array}$ & - & 5 & 6 & - & 11 & 2 & 34 & 8 & 4 & - & - & - & - & - \\
\hline $\begin{array}{l}\text { Tilapia rendalli } \\
\text { (Boulenger, 1896) }\end{array}$ & - & - & - & - & - & - & - & - & - & - & - & - & - & 4 \\
\hline $\begin{array}{l}\text { Tilapia sparmanii } \\
\text { (Smith, 1840) }\end{array}$ & - & - & - & - & - & - & - & - & - & - & - & - & - & 2 \\
\hline
\end{tabular}


Table 4. Mean values for Water Quality results sampled in the Crocodile River and its tributaries during Summer season (December 2012-March 2013).

\begin{tabular}{|c|c|c|c|c|c|c|c|c|c|c|c|c|}
\hline Physico-chemical variables & CR1 & CR2 & CR3 & CR4 & CR5 & CR6 & CR7 & CR8 & CR9 & CR10 & ER1 & KR1 \\
\hline $\mathrm{Cl}(\mathrm{mg} / \mathrm{L})$ & 1.7 & 3.2 & 1.5 & 2.0 & 17.1 & 13.1 & 11.9 & 11.2 & 39.9 & 104.9 & 52.6 & 11.7 \\
\hline $\mathrm{EC}\left(\mathrm{mS} / \mathrm{m}^{-1}\right)$ & 5.8 & 11.4) & 11.4 & 12.6 & 23.9 & 19.8 & 18.2 & 16.9 & 33.5 & 84.1 & 55.7 & 35.5 \\
\hline $\mathrm{Mg}(\mathrm{mg} / \mathrm{L})$ & 4.0 & 9.7 & 5.5 & 7.6 & 10.9 & 5.3 & 10.8 & 6.3 & 22.1 & 27.5 & 21.6 & 19.3 \\
\hline $\mathrm{Na}(\mathrm{mg} / \mathrm{L})$ & 2 & 2.8) & 1.9 & 4.0 & 16.2 & 12.9 & 11.5 & 11.6 & 22.9 & 86.5 & 46.4 & 15.0 \\
\hline $\mathrm{NH}_{4}(\mathrm{mg} / \mathrm{L})$ & 0.025 & 0.025 & 0.05 & 0.025 & 0.025 & 0.04 & 0.025 & 0.025 & 0.025 & 0.0025 & 0.0025 & 0.025 \\
\hline $\mathrm{NO}_{3}(\mathrm{mg} / \mathrm{L})$ & 0.025 & 0.08 & 2.4 & 0.025 & 0.025 & 0.2 & 0.025 & 0.19 & 0.43 & 4.1 & 0.0025 & 0.5 \\
\hline $\mathrm{pH}$ & 7.8 & 7.5 & 7.3 & 7.7 & 8.1 & 7.8 & 7.8 & 7.6 & 8.1 & 7.9 & 8.1 & 8.2 \\
\hline $\mathrm{PO}_{4}(\mathrm{mg} / \mathrm{L})$ & 0.005 & 0.005 & 0.005 & 0.005 & 0.005 & 0.008 & 0.009 & 0.01 & 0.02 & 0.4 & 0.007 & 0.02 \\
\hline $\mathrm{SO}_{4}(\mathrm{mg} / \mathrm{L})$ & $1.5(0)$ & 1.5 & 1.5 & 2.2 & 27.1 & 19.4 & 18.8 & 16.2 & 38.4 & 25.4 & 85.8 & 36.2 \\
\hline Salinity (ppt) & 0.0428 & 0.0656 & 0.0705 & 0.06 .6 & 0.138 & 0.152 & 0.127 & 0.139 & 0.227 & 0.299 & 0.358 & 0.315 \\
\hline TDS (mg/L) & 60.5 & 96.9 & 104 & 93.9 & 205 & 228 & 192 & 206 & 335 & 438 & 528 & 460 \\
\hline Temperature $\left({ }^{\circ} \mathrm{C}\right)$ & 16.9 & 16.6 & 17 & 14.1 & 17.2 & 15.2 & 19.6 & 20 & 21.8 & 21.9 & 16.4 & 20.2 \\
\hline
\end{tabular}

Table 5. Mean values for water quality results sampled in the Crocodile River and its tributaries during Winter Season (June-August 2012).

\begin{tabular}{|c|c|c|c|c|c|c|c|c|c|c|c|c|}
\hline Physico-chemical variables & CR1 & CR2 & CR3 & CR4 & CR5 & CR6 & CR7 & CR8 & CR9 & CR10 & ER1 & KR1 \\
\hline $\mathrm{Cl}(\mathrm{mg} / \mathrm{L})$ & - & 6 & 5 & 3.9 & 17 & - & - & 19 & 26 & 38.3 & 47.3 & 17.9 \\
\hline $\mathrm{EC}\left(\mathrm{mS} / \mathrm{m}^{-1}\right)$ & 8.8 & 9.6 & 13.1 & 14.7 & 22.9 & 24.7 & 21.5 & 17.1 & 42.9 & 48.4 & 57.96 & 58.8 \\
\hline $\mathrm{Mg}(\mathrm{mg} / \mathrm{L})$ & 40.0 & 5.0 & 5.0 & 4.4 & - & 10 & 5.0 & 0.025 & 16.7 & 20 & 15.5 & 27.5 \\
\hline $\mathrm{Na}(\mathrm{mg} / \mathrm{L})$ & 2 & 5.3 & - & - & - & - & - & - & - & - & 45.1 & 30.8 \\
\hline $\mathrm{NH}_{4}(\mathrm{mg} / \mathrm{L})$ & - & 0.025 & 0.025 & 0.1 & 0.025 & 0.1 & - & - & 0.1 & 0.1 & 0.025 & 0.06 \\
\hline $\mathrm{NO}_{3}(\mathrm{mg} / \mathrm{L})$ & - & 0.025 & 7.3 & 0.1 & 0.025 & 0.2 & - & - & - & 0.1 & 0.6 & - \\
\hline $\mathrm{PH}$ & 7.7 & 7.7 & 7.7 & 7.8 & 7.6 & 7.5 & 7.7 & 7.6 & 7.9 & 8.0 & 8.1 & 8.2 \\
\hline $\mathrm{PO}_{4}-\mathrm{P}(\mathrm{mg} / \mathrm{L})$ & 0.1 & $0.2)$ & 0.1 & 0.1 & 0.2 & 0.1 & 0.7 & 0.2 & 0.1 & 0.1 & 0.03 & 0.04 \\
\hline $\mathrm{SO}_{4}(\mathrm{mg} / \mathrm{L})$ & 88.1 & 0.1 & 88.1 & 3.3 & 20 & 105 & 19 & - & 39 & 103 & 82.9 & 52.5 \\
\hline Salinity (ppt) & 0.0362 & 0.0603 & 0.0648 & 0.065 & 0.065 & 0.132 & 0.118 & 0.124 & 0.192 & 0.321 & 0.318 & 0.284 \\
\hline TDS (mg/L) & 52.5 & 87.9 & 95.5 & 98.5 & 98.5 & 196 & 175 & 184 & 284 & 327 & 476 & 422 \\
\hline Temperature $\left({ }^{\circ} \mathrm{C}\right)$ & 13.2 & 17 & 15.9 & 11.8 & 11.8 & 19.3 & 20.1 & 18.9 & 20 & 20.6 & 12.3 & 17.4 \\
\hline
\end{tabular}


Scientific Research Publishing (SCIRP) is one of the largest Open Access journal publishers. It is currently publishing more than 200 open access, online, peer-reviewed journals covering a wide range of academic disciplines. SCIRP serves the worldwide academic communities and contributes to the progress and application of science with its publication.

Other selected journals from SCIRP are listed as below. Submit your manuscript to us via either submit@scirp.org or Online Submission Portal.
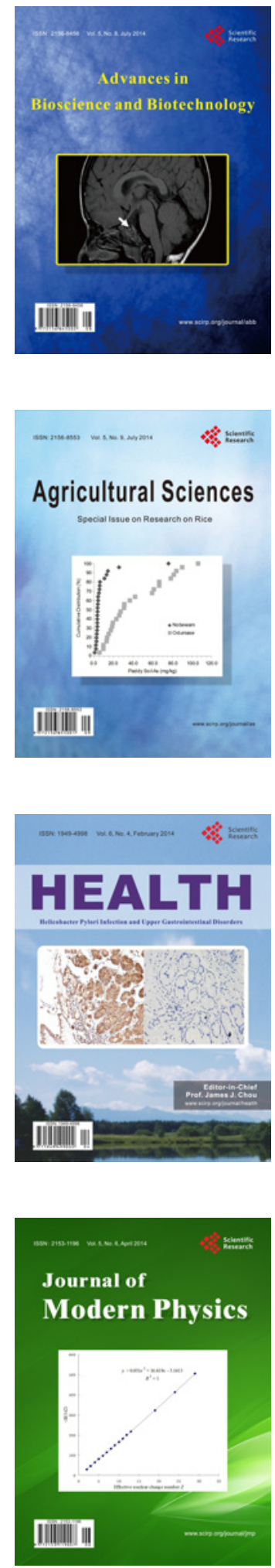
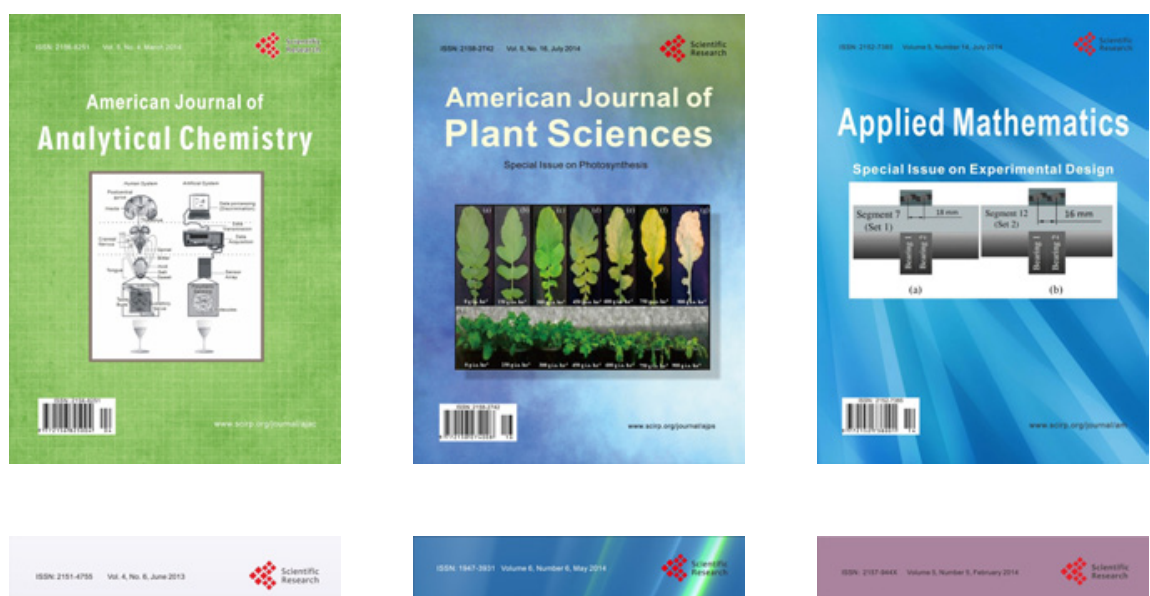

Creative Education
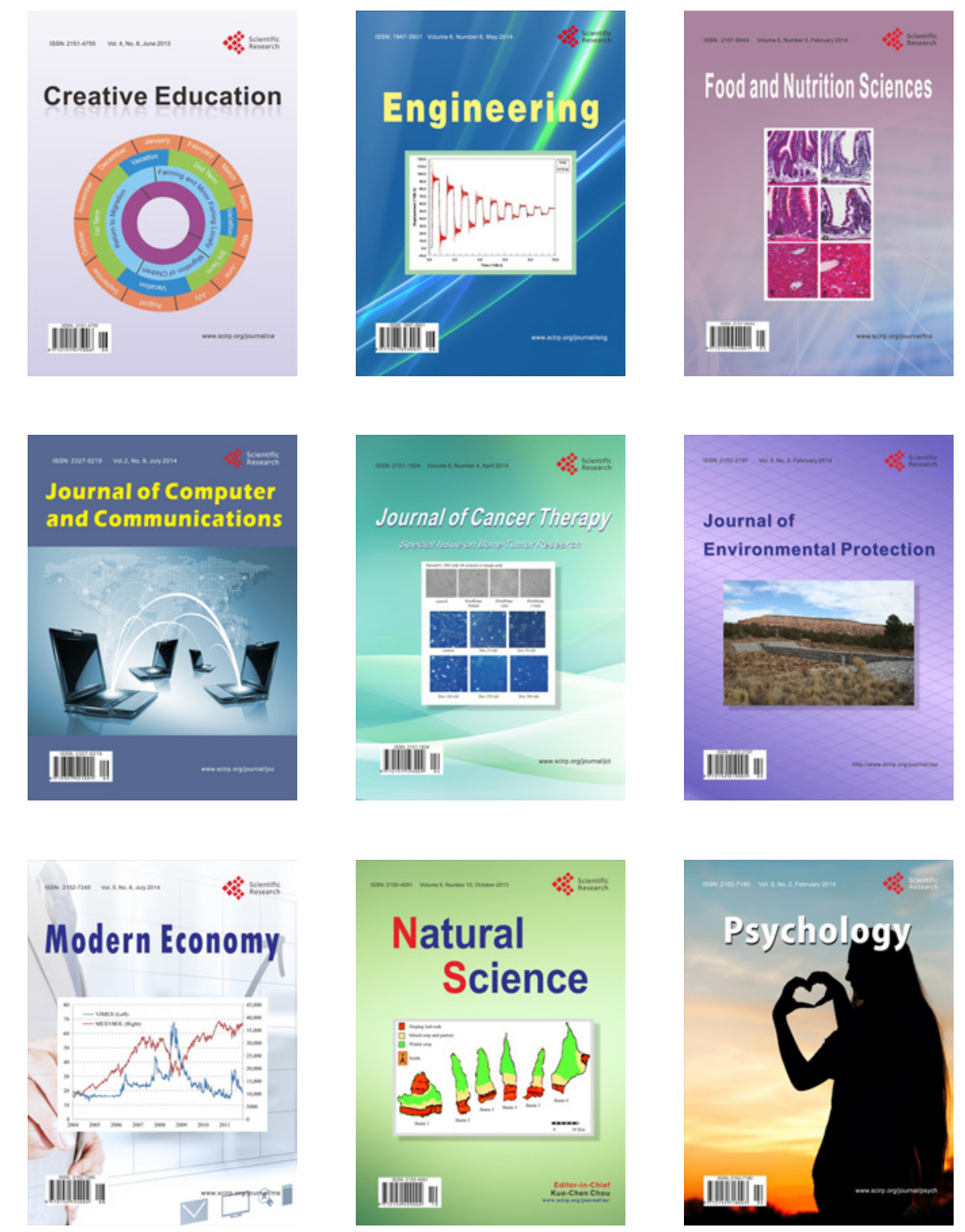